\title{
Work-family conflicts of Indian women entrepreneurs: A preliminary report
}

Das, Mallika

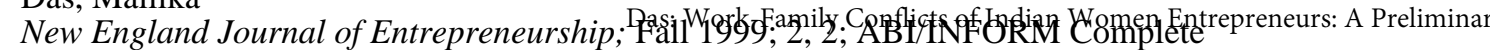
pg. 39

\section{Work-Family Conflicts of Indian Women Entrepreneurs: A Preliminary Report}

\section{Mallika Das}

This article examines the work-family conflicts faced by women entrepreneurs in South India. The results indicate that female entrepreneurs in India may not be encountering the same levels of work-family conflict as their Western counterparts. The women entrepreneurs studied seem to experience very little conflict in their spousal, parental, or homemaker roles. Reasons for the lower level of work-family conflict experienced by these women are also explored.

$\mathbf{T}$ he number of women starting their own companies has been on the increase in many countries. For example, as early as 1990 , over 50 percent of the new businesses in Canada were started by women. ${ }^{1}$ It is predicted that by the year 2000, one in three Canadian small business owners will be a woman. ${ }^{2}$ Women are increasingly turning to entrepreneurship as a way of coping with the "glass ceiling" that seems to prevent them from reaching top managerial levels in organizations. ${ }^{3}$ Others find that entrepreneurship provides greater satisfaction and flexibility. ${ }^{4}$ Women often report that they left the corporate world because of difficulties with balancing work and family responsibilities. ${ }^{5}$

Several Asian countries, such as Indonesia and Singapore, have also experienced increases in the number of women starting their own companies. ${ }^{\circ}$ In India, while women have traditionally been a smaller part of the workforce when compared to men, the proportion of women classified as "employers and workers on own account" has been significant-nearly 30 percent. $^{7}$

At the same time, women remain the main caregivers of families, with primary responsibility for childcare and eldercare. They also continue to act as "homemakers." These roles can lead to work-family conflicts as women face increasing work commitments without significant decreases in family responsibilities. Balancing work and family and the increased stress that it brings has been linked to increased health risks, less effective parenting, and decreased life satisfaction. ${ }^{8}$ Since entrepreneurs are often assumed to have greater job flexibility and hence greater ability to accommodate family needs, the selfemployed may have higher levels of work-family conflicts. ${ }^{9}$ As the number of women entrepreneurs increases and their businesses continue to expand, understanding their work-family issues will become increasingly relevant.

While there have been several studies conducted on women managers in India, ${ }^{10}$ very little attention has been paid to female entrepreneurs in the country. Studies in Canada and the United States" indicate that the woman entrepreneur is quite different from the woman manager.

This article attempts to fill the gap in the literature by focusing on women entrepreneurs in India. The primary focus here is on the work-family conflicts faced by women in two southern provinces in India (i.e., Kerala and Tamil Nadu). Examining the differences between the experiences of women entrepreneurs from India and those from Western nations may help us understand the impact of cultural differences on women's entrepreneurial activities. Also, tactics used by females in other nations to cope with work-family conflicts may provide insights into how these issues can be handled by women in other regions.

\section{Literature Review}

While women face several problems in the start-up and continued running of their businesses, many researchers feel that the main problem women entrepreneurs face is the tension between their personal lives and career pursuits. ${ }^{12}$ Research from the developed world indicates that women face difficulties in balancing their professional and family lives. For example, Neider ${ }^{13}$ studied female entrepreneurs in Florida and found that tension between personal life and career was a major problem for these women. Husbands are generally not very involved in their wives' businesses or supportive of them. ${ }^{14}$ Men also seem to expect women to continue with their household duties despite the demands of their business responsibilities. ${ }^{15}$ This, perhaps, is not surprising for the role of entrepreneur does not conform with the traditional roles that women are expected to play in society. These factors, and others, may result in female businessowners facing more work-family conflicts than their male counterparts.

Work-family conflict is often defined as inter-role conflict or conflict experienced when the role pressures from work and family are incompatible. ${ }^{16}$ Two types of inter-role conflict are noted in the literature: work interfering with family and family interfering with work. ${ }^{17}$ For women, work interfering with family is more common than family interfering with work. ${ }^{18}$ Hence, this study focuses on the former. Greenhaus and Beutell identified three types of work-family conflicts:

1. Time-based: The time demands of the two roles conflict with each other.

2. Strain-based: Symptoms of stress from one role spill over to the other. 
3. Behavior-based: Behaviors that are useful in one role cause problems in the other.

A woman's family role can be divided into three specific roles: spouse, parent, and homemaker. When women experience work-family conflicts, one or more of these roles are affected. For example, Belcourt, Burke and LeeGosselin found that 21 percent of the female entrepreneurs they studied felt that being an entrepreneur has a negative impact on their parental role. Similarly, Lee-Gosselin and Grise found that 28 percent of their sample of Quebec women entrepreneurs felt that their role as entrepreneurs damaged their family life. The above study found that women entrepreneurs felt that being an entrepreneur also changed their relationship with their spouse.$^{19}$ In a study of Australian women entrepreneurs, Breen, Calvert and Oliver $^{20}$ found that work-family conflicts were a major problem for these women and that lack of time to spend with family members led to most of the family tensions.

Past research indicates that several factors affect work-home conflicts. These factors include family size and support, marital and life satisfaction, and size of the firm. Women in larger families and those with younger children are more likely to experience work-home role conflict than others. ${ }^{21}$ Another family-related variable that affects workfamily conflict is the degree of family support. Support from family members (especially the spouse) can help reduce and/or relieve perceived work-home conflict. ${ }^{22}$ The emotional support provided by a supportive family has also been linked to a female entrepreneur's chances for succeeding in her business venture. ${ }^{23}$ The degree of social support a woman has also seems to have an impact on the degree of work-family conflicts experienced by her. ${ }^{24}$

Almost all of the research mentioned above used samples drawn exclusively from the developed world. Given the cultural, economic, and technological differences between a developing nation, such as India, and the developed world, it is likely that some of the findings mentioned above may not be applicable to the Indian woman entrepreneur. For example, studies from developed nations indicate that most work-family conflicts center on the support (or lack of it) received from one's spouse in child care and household activities. However, in several developing nations (including India), women have higher levels of extended family support for coping with the demands of running a business and taking care of a family. ${ }^{26}$ They also have access to paid household help. On the other hand, besides their parental and spousal roles, women in these nations have several other roles to play (e.g., daughter, sister, in-law). These roles become more important in a country like India as it is not uncommon to find two or three generations living together in one household. Such roles may take up considerable amounts of a woman's time and effort. For example, while paid household help may reduce some of a woman's typical "homemaker" duties, she often has others (not common in the Western world) to handle (e.g., cleaning the "pooja" or prayer room-part of the duties of a daughter-in-law). The number of social activities and religious celebrations that a woman has to participate in are also greater in a country like India. Studies of Indian women managers indicate that they spend a considerable amount of time on these social role demands. ${ }^{27}$

The present study focuses on extending the research done in the developed world on problems faced by women entrepreneurs to a developing country (i.e., India). Because of language and subcultural differences found in India, the study was limited to two provinces in Southern India (Tamil Nadu and Kerala) that the researcher was very familiar with. While the study examined various issues such as start-up problems faced by women entrepreneurs in India, the type of assistance they had received, the nature of their enterprises, etc., this article deals only with the work-family conflicts (especially with time-based and strain-based conflicts) faced by these women. Thus, the article deals primarily with the impact of the women's entrepreneurial role on their spousal, parental, and homemaker roles.

\section{Research Methodology}

The local governmental agencies in charge of developing and assisting women entrepreneurs and local women entrepreneurs' associations in Tamil Nadu and Kerala were contacted. Using the lists provided by these organizations and after discussions with the people in charge of these organizations, a list of women entrepreneurs was developed. Only firms that employed at least two other workers and had been in operation for at least two years were included in the study. A two-year cut-off was chosen to eliminate firms that were strugging to get established. Since the focus was on female entrepreneurs who were actively involved in starting and running their businesses (as opposed to those who were silent partners with their spouses), only women who were known to these agencies as active owner-managers were contacted. Care was taken to include women in different types of businesses. Clearly, this sample is not a probability sample of the population of women entrepreneurs in these provinces. It was biased in favor of women entrepreneurs who were seen as successful (in terms of survival and overall growth) by these agencies and who were active in the day-to-day management of their businesses. However, it did include a wide range of firms in terms of sales volume, sector, financial resources, labor force, and other factors. (Details of the sample are provided in Exhibit 1).

The information was collected through in-depth personal interviews with the respondents. The interviews were two to three hours in length and were followed by visits to 


\section{Exhibit 1}

Sample Characteristics

Type of Business

$\begin{array}{lrr}\text { Manufacturing } & 19 & (54 \%) \\ \text { Service } & 3 & (9 \%) \\ \text { Retailer } & 2 & (6 \%) \\ \text { Other } & 6 & (17 \%) \\ \text { Wholesale } & 5 & (14 \%)\end{array}$

Number of Full-time Employees

$\begin{array}{lrr}5 \text { or under } & 17 & (47 \%) \\ 11-20 & 9 & (27 \%) \\ 6-10 & 2 & (6 \%) \\ 21+ & 7 & (20 \%)\end{array}$

Ownership

$\begin{array}{lll}100 \% \text { Self } & 23 & (66 \%) \\ \text { Partnership } & 11 & (33 \%)\end{array}$

Source of Funds

$\begin{array}{lrr}\text { Self } & 15 & (43 \%) \\ \text { Banks } & 15 & (43 \%) \\ \text { Spouse/family } & 3 & (9 \%) \\ \text { Other } & 2 & (6 \%)\end{array}$

Sales Volume

$\begin{array}{lrl}\text { Under Rs } 100,000 & 8 & (23 \%) \\ \text { Rs } 1,000,001- & & \\ \quad 2,000,000 & 6 & (17 \%) \\ \text { Rs } 100,001-500,000 & 13 & (37 \%) \\ \text { Over Rs 2,000,001 } & 4 & (11 \%) \\ \text { Rs } 500,001- & & \\ 1,000,000 & 4 & (11 \%)\end{array}$

Expected Growth in Sales (next two years)

$$
\begin{aligned}
& \text { Over } 10 \%=16 \\
& 1-10 \%=15 \\
& \text { None/-ve }=4
\end{aligned}
$$

\section{Reasons for Starting a Business ${ }^{a}$}

$\begin{array}{lrr}\text { Had time/hobby } & 20 & (28 \%) \\ \begin{array}{l}\text { Family/spouse } \\ \quad \text { had business }\end{array} & 5 & (7 \%) \\ \begin{array}{l}\text { Financial reasons } \\ \text { Challenge, self }\end{array} & 16 & (22 \%) \\ \quad \text { satisfaction } & 17 & (23 \%) \\ \text { Other } & 12 & (20 \%)\end{array}$

a. Numbers add up to more than 35 , as respondents were asked to provide their top two reasons for starting a business.

the stores/production facilities in order to gain a better understanding of their operations. A questionnaire was used to guide the researcher during data collection. The study is part of an effort to develop case studies on women entrepreneurs, and hence the focus was on in-depth research as opposed to having a large sample size. In both provinces, data was collected from two large cities that were major commercial centers. The cities were chosen based on discussions with the agencies and were based on the number of women entrepreneurs in the area. The final sample consisted of 35 women. The data was collected over a two-month period in early 1994.

All three aspects of a woman's family role-as a spouse, parent and homemaker-were examined using the appropriate subscales (homemaker, parent, and spouse) of Small and Riley's $\mathrm{s}^{28}$ spillover of work into nonwork roles scale. Small and Riley reported that all subscales attained an acceptable level of internal reliability (the lowest being .75). The internal consistency for the overall measure was $.93 .^{29}$ This scale has been used by other researchers to measure work-family conflicts in Asian setting $\mathrm{s}^{30}$ with high alpha reliabilities. The subscale for each role had five items. These questions dealt with time-based (e.g., "my business keeps me from spending time with my spouse") and strain-based conflicts (e.g., "business worries interfere with my relationship with my spouse"). Each item was scored on a five-point scale of strongly agree (5) to strongly disagree (1) with 3 being the neutral point. Respondents were also asked to provide information on their satisfaction with family life, the progress of their business, and life in general.

\section{Results and Discussion}

The majority of the women entrepreneurs studied were operating their businesses as private limited companies that were 100 percent owned by themselves. Only a third 
were partnerships-with the spouse $(31 \%)$ or a family member (44\%) being the most common partner. The women were mostly young with nearly 70 percent being under 44 years of age. Almost all $(n=32)$, were married ( 3 were widowed), with most being married over 10 years $(n=28)$. All had school-going or older children. They were fairly well educated with over 50 percent $(n=20)$ holding a university degree. The demographic profile of these Indian women entrepreneurs is very similar to the one found in studies from other Asian nations. ${ }^{31}$

The businesses owned by these women varied in nature. Unlike women from other Asian nations, ${ }^{31}$ a significant proportion $(54 \%)$ were in manufacturing (products manufactured ranged from kerosene stoves and automobile parts to wire meshes). While some were small in terms of number of employees or sales volume, several were fairly large firms. For example, over 20 percent had more than 20 employees and 28 percent had sales volumes in excess of Rs $1,000,000$ (U.S. $\$ 30,000$ ). Thus, most of these firms were not microenterprises. A look at their reasons for starting their own businesses indicates that money was not the major motivating factor for these women. However, these were not wealthy women who were running a business as a hobby. They were typically middle-class women. Exhibit 1 provides details of key sample characteristics.

\section{Work-Family Conflicts}

The women entrepreneurs in this study did not feel that having their own business affected their roles as spouse, parent, or homemaker very much. As can be seen from Exhibit 2, the mean score for the questions on their spousal role was 2.3 and parental role was 2.55 (a lower score indicates lower conflict level). Of the roles examined (spouse, parent, and homemaker), the homemaker role seems to be the only one that was suffering-at least to a small degree. The mean score on the questions related to this role was 3.15-which is above the neutral point and hence indicates a slight amount of role conflict. The impact on the homemaker role seems to come from slight timebased conflict, lower energy levels, and general difficulty in getting household chores done. For example, the women indicated that their business responsibilities made it a little difficult for them to do household chores (3.22). Interestingly, the respondents felt that being an entrepreneur helped them improve their relationship with their spouse. When probed further, they most often stated that they had something interesting to share with their partners. The other two family roles (parent and homemaker) did not benefit from the woman's entrepreneurial role.

An examination of the type of conflict the women faced in each family role indicates that they faced very little time pressure and hence experienced low levels of time-based conflicts. For example, when asked if their business inter-

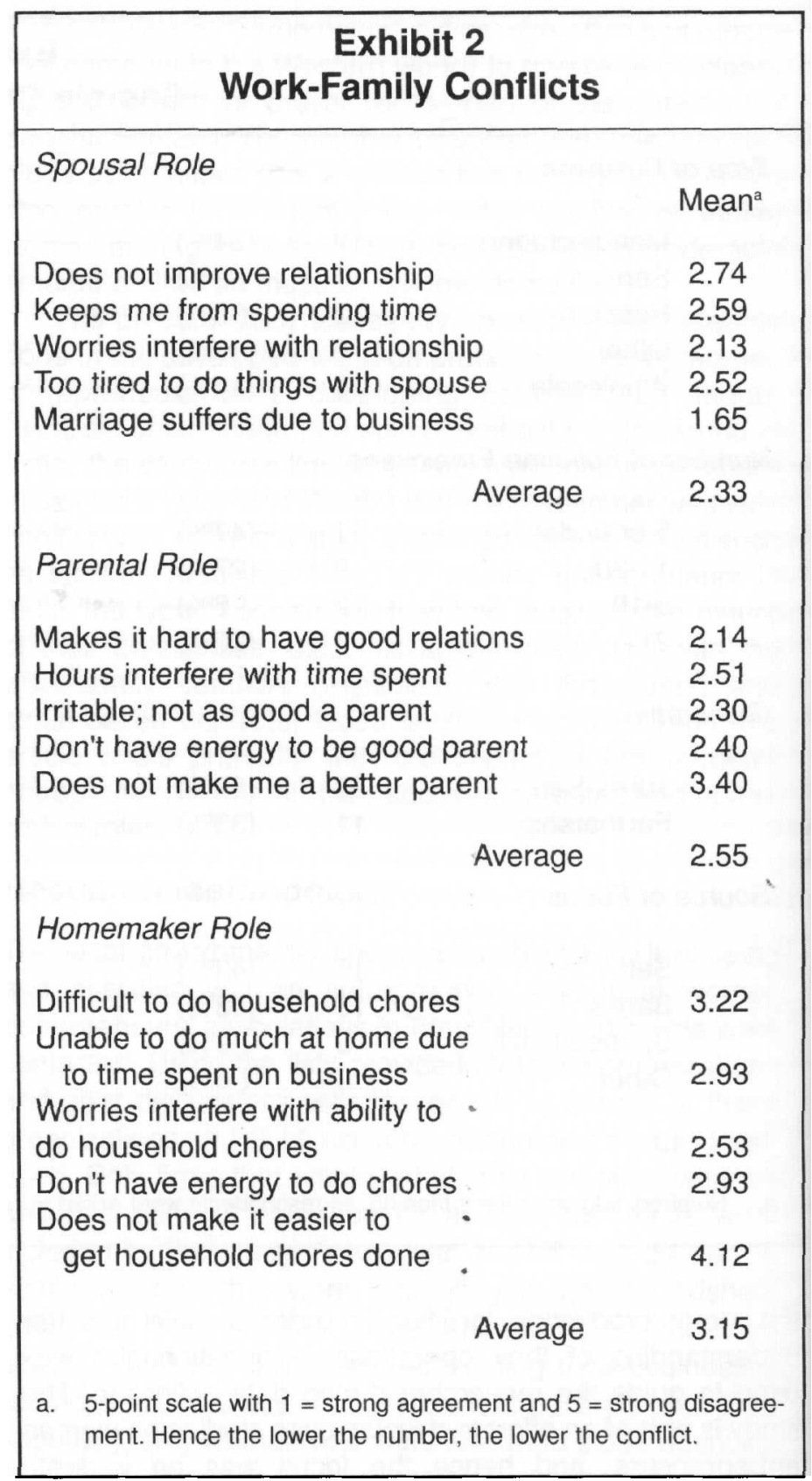

ests keep them from spending time with their spouse or children, most respondents said "no." Similarly, they do not seem to feel that being an entrepreneur prevents them from spending time with their children in any major way. The women also did not face significant levels of strainbased conflict. As Exhibit 2 indicates, they felt that their entrepreneurial role did not interfere with their relationship with their spouse or make them too tired to do things with their spouse. Similarly, they did not feel that their business interests made them irritable (and hence not a good parent) or reduced their energy to the level that they were not good parents. 
Studies from developed nations indicate that role conflict would be higher when the family size is larger, when younger children are present and when the business is larger in size. ${ }^{33}$ Since most of them had fairly young children, large families (all had at least four-person households and were similar to the typical Indian household in size), and most operated small businesses of reasonable size (as opposed to microenterprises), one would expect them to have high levels of work-family conflicts.

Two major factors-the high levels of spousal and extended family support-may explain the lower levels of work-family conflicts found in this study. As Holahan and Gilber and Den, Hassan, and Jivan ${ }^{34}$ note, support from family members (especially the spouse) is a major factor in reducing work-family conflict. Other contributing factors may be the overall higher satisfaction with life in general, marital life and the progress of their business enterprises.

Most of the respondents (over $70 \%$ ) said that their spouse was either happy or very happy that they owned their own business. Over 43 percent said that their spouse was happy with the level of commitment that they had to their business and over 70 percent said that their spouse offered them emotional support. Thus, even though their partners did not offer much help with household chores or with childrearing, the women were overall happy with the level of support they received from their marital partners. This is also reflected in the fact that five of the women rated spousal support as a key reason for success. Even among the others, many had stated that a woman cannot hope to succeed without support from her spouse. The high degree of spousal support that these women enjoyed might be the result of the stable, satisfactory nature of their marriages. Most were in fairly long-lasting and happy marriages with over 80 percent stating that they were "satisfied" or "very satisfied" with their marital life.

Another possible reason for the lower level of role conflict might be the fairly high level of extended family support that these women enjoy. Many had highly supportive parents and in-laws and 25 percent had an extended family member living with them. (Exhibit 3 provides details related to spousal and other support.) This may have reduced the burden of childcare for these women. Most of these women had someone to help them with their household chores-either a part-time or full-time maid. Interestingly, most of these women felt that their experiences in a jointfamily system had actually helped them gain valuable people-management skills. For example, one woman, who owned a successful printing press, commented that managing her workforce of 10 employees seemed easy after managing a home with over 10 members (including her inlaws, two brothers-in-law, a sister-in-law and other family members). The benefits of having an extended family seem to be flowing both ways - with the business and family gaining from each other.

\begin{tabular}{|c|c|}
\hline \multicolumn{2}{|c|}{$\begin{array}{c}\text { Exhibit } 3 \\
\text { Spousal and Other Support }\end{array}$} \\
\hline \multicolumn{2}{|l|}{ Spousal Role } \\
\hline & Mean $^{a}$ \\
\hline Provides me with emotional support & 3.91 \\
\hline Is happy that I run my own business & 3.89 \\
\hline $\begin{array}{l}\text { Is happy with my level of commitment } \\
\text { to my business }\end{array}$ & 3.63 \\
\hline Works long hours at his job & 3.17 \\
\hline Shares equally in household chores & 2.00 \\
\hline Takes primary responsibility for children & 1.26 \\
\hline Provides me with financial support & 3.14 \\
\hline Average & 3.00 \\
\hline \multicolumn{2}{|l|}{ Other Relevant Facts } \\
\hline$\%$ with parents/in-laws living at home & $25 \%$ \\
\hline$\%$ with full-time household help & $51 \%$ \\
\hline$\%$ with part-time household help & $60 \%$ \\
\hline \multicolumn{2}{|c|}{$\begin{array}{l}\text { a. 5-point scale with } 1=\text { strong disagreement and } 5=\text { strong dis- } \\
\text { agreement. Hence, the higher number, the higher the support. }\end{array}$} \\
\hline
\end{tabular}

The high level of spousal support experienced by the respondents might be due to several reasons. For example, Granrose, Parasuraman and Greenhaus ${ }^{35}$ state that besides individual characteristics, the following factors may affect the level of spousal support: the availability of resources (time, money, or information), children are present, the family is valued, and if relative positions in family and work do not violate gender or family role norms. While spouses were not interviewed separately, the interviews with the women indicated that most of these conditions did apply in the case of these respondents. The women indicated that they made sure they did all their expected "duties" before they started the typical workday. In other words, they seem to have taken special care not to violate the gender or family role norms. In a traditional society like India, this may be a critical factor in avoiding work-family conflicts.

The lower level of role conflict may also be the result of greater levels of satisfaction with the business and life in general. As Stoner et al. ${ }^{36}$ found, higher levels of work-family conflict of female entrepreneurs were associated with lower levels of satisfaction with life in general and the state of their businesses. They found no significant relationship between work-family conflicts and a woman's marital status, number of children, or hours worked. ${ }^{37}$ The women in this study had a high level of satisfaction with life in general (4.3), their marriage (4.1), and their role as a parent (3.8). Most of these women were also highly satisfied with 
the way their business was progressing (mean=4.1) with over 80 percent stating that they were either "satisfied" or "very satisfied" with the way their business was progressing. Perhaps their satisfaction with the progress of their business made them happy with their life in generalwhich, in turn, led to less tension between their work and family roles.

The lower levels of work may also be attributable to the size of the firms that these women owned. Since they were primarily small business owners, their companies may not yet be at the level at which significant time- and strainbased pressures would be felt. For example, most of the women did not have to travel on business or stay away from their families for long periods of time. However, even those in larger firms (e.g., those with sales volumes in excess of Rs. 1,000,000 and/or over 20 employees) did not report high levels of work-family conflicts.

\section{Conclusions}

This study examined the work-family conflicts faced by female entrepreneurs in India. While many studies in Western nations have examined this issue in the context of women entrepreneurs, very few studies have focused on women from the developing world. This exploratory study indicates that there may be both similarities and differences between the experiences of women from the developing world and the developed world. Specifically, this study found that the extent of work-family conflict that these women face may differ. For the present sample at least, work-family conflict does not seem to be as high as that found in studies based on samples from the developed world. The high amount of spousal and extended family support, combined with the availability of cheap household help may account for the lower level of work-family conflict found in the study. This, combined with their overall satisfaction with their life in general, marriages, and the progression of their business ventures may have further reduced the extent of work-family conflicts faced by these women.

From a female entrepreneur's point of view, this study highlights the importance of gaining spousal and family support for entrepreneurial activities. Developing social support systems may be a good strategy for women who do not have spousal or family support systems. The women in this study also seemed to have prioritized their family roles and given more importance to spousal and parental roles than the homemaker role. While this might reflect the availability of paid help in India, it probably also indicates that such prioritization may have helped these women achieve a work-family balance. Also, these women always placed their families first and generally started their businesses after their children started going to school. Studies of Asian women in Britain and other nations have found similar priorities. For example, Dhaliwal ${ }^{38}$ found in her study of South Asian female entrepreneurs in Britain that their children were the primary focus of these women. Most of the respondents in her study had started their businesses only when they felt that their children needed less of their time (e.g., after their children started attending school or left home). Once they started their businesses, these women were very involved in their companies and made their own decisions. Again, these women were more satisfied with their work and family lives than found in other studies. ${ }^{39}$

The present study was limited to two provinces in South India and, being exploratory in nature, had a small sample size. The sample consisted of fairly well-established, successful women entrepreneurs. Hence a larger study with a more representative sample is required before firm conclusions can be drawn on the nature of work-family conflicts faced by women entrepreneurs in India. Further insights may also be gained by collecting more specific information on the number of hou's spent by women entrepreneurs on housework; business activities; and parental, spousal, and other roles. As Gutek et al. note, this may pro. vide a more rational basis for looking at the work-family conflicts of women entrepreneurs.

\section{Endnotes}

1. A. Comper, "Women and Banking: From Rhetoric to Reality" in L. Heslop, ed., Managing Change Through Global Networking. Canadian Consortium of Management Schools, 1991.

2. F. E. Ferguson and J. R. Durup, "Work-Family Conflict and Entrepreneurial Women: A Literature Review," Journal of Small Business and Entrepreneurship 14, no. 1 (1997), pp. 30-51.

3. A. M. Morrison, R. P. White, E. Van Velsor, and the Centre for Creative Leadership, Breaking the Glass Ceiling: Can Women Reach the Top of America's Largest Corporations? Reading, MA: Addison Wesley Publishers Inc., 1987.

4. M. Belcourt, R. J. Burke, and H. Lee-Gosselin, The Glass Box: Women Business Owners in Canada. Background paper published by the Canadian Advisory Council on the Status of Women, 1991.

5. E. H. Buttner and D. P. Moore, "Women's Organizational Exodus to Entrepreneurship: Self-Reported Motivations and Correlates with Success," Journal of Small Business Management 35, no. 1 (1997), pp. $34-46$. 
6. V. Licuanan, Women Entrepreneurs in Southeast Asia. Asian Institute of Management, Manila, Philippines, 1992.

7. International Labour Organization Women in Economic Activity: A Global Statistical Survey (19502000). A joint publication of ILO and INSTRAW, 1985.

8. J. Greenhaus and N. Beutell, "Sources of Conflict Between Work and Family Roles," Academy of Management Review 10 (1985), pp. 76-88; and P. Voydanoff, "Work and Family: A Review and Expanded Conceptualization," Journal of Social Behaviour and Personality 3, no. 4 (1988), pp. 1-22.

9. Ferguson and Durup, "Work-Family Conflict and Entrepreneurial Women: A Literature Review."

10. For example, M. Kishore, Developmental Needs of Trainers of Women Managers: The Indian Context. Study Report on Women in Management, International Management Institute, 1992; J. M. Mishra, K. Harsh Vardhan, and V. Mishra, "Women Managers in India and US: An Analysis of Attitudes, Myths and Skills (Part I)," Indian Management 25, no. 3 (1986), pp. 25-30; J. M. Mishra, K. Harsh Vardhan, and V. Mishra, "Women Managers in India and US: An Analysis of Attitudes, Myths and Skills (Part II)," Indian Management 25, no. 6 (1986), pp. 25-29; J. Marie, "Women in Public Administration and Management," Indian Management 27, no. 4 (1988), pp. 4-11; A. Naik, Development Programme for Women in Management. Study Report on Women in Management, Centre for Organization Development, Hyderabad, India, 1992; S. Rohtagi, "Woman Executive and the Social Scenario," Indian Management 27 no. 4 (1988), pp. 12-13; N. K. Singh, L. lyer, and A. Gupta, "Attitude Towards Women Managers," Indian Management 23, no. 11 (1984), pp. 3-30; and I. T. Vaz, "Women Managers in Banking Sector," Indian Management 27, no. 4 (1987), pp. 14-16.

11. For example, L. Neider, "A Preliminary Investigation of Female Entrepreneurs in Florida," Journal of Small Business Management 25, no. 3 (1987), pp. 22-29; and L. A. Stevenson, "Against All Odds: The Entrepreneurship of Women," Journal of Small Business Management (October 1986), pp. 30-44.

12. See for example, Belcourt, Burke, and Lee-Gosselin, The Glass Box: Women Business Owners in Canada; and H. Lee-Gosselin and J. Grise, "Are Women Owner-Managers Challenging Our Definitions of Entrepreneurship? An In-Depth Survey," Journal of Business Ethics 9 (April-May 1990), pp. 423-35.

13. Neider, "A Preliminary Investigation of Female Entrepreneurs in Florida."

14. J. F. DeCarlo and P. R. Lyons, "A Comparison of Selected Personal Characteristics of Minority and Nonminority Female Entrepreneurs," Proceedings of the 39th Annual Meeting of the Academy of Management (1979), pp. 369-73; and R. Goffee and R. Scase, Women in Charge: The Experiences of Women Entrepreneurs. London: Allen \& Irwin, 1985.

15. Goffee and Scase, Women in Charge: The Experiences of Women Entrepreneurs.

16. J. H. Greenhaus and R. E. Kopelman, "Conflict Between Work and Non-work Roles: Implications for the Career Planning Process," Human Resources Planning (January 1981), pp. 1-10; and Voydanoff, "Work and Family: A Review and Expanded Conceptualization."

17. B. Gutek, S. Searle, and L. Klepa, "Rational Versus Gender Role Explanations for Work-Family Conflict," Journal of Applied Psychology 76 (1991), pp. 56-68.

18. Ibid.; and S. Foley and G. N. Powell, "Reconceptualizing Work-Family Conflict for Business/Marriage Partners: A Theoretical Model," Journal of Small Business Management 35, no. 4 (1997), pp. 36-47.

19. Belcourt, Burke, and Lee-Gosselin, The Glass Box: Women Business Owners in Canada.

20. Breen, C. Calvert, and J. Oliver, "Female Entrepreneurs in Australia: An Investigation of Financial and Family Issues," Journal of Enterprising Culture 3, no. 4 (1995), pp. 445-461.

21. P. M. Keith and R. B. Shafer, "Role Strain and Depression in Two Job Families," Family Relations (July 1980), pp. 483-488; and Greenhaus and Kopelman, "Conflict Between Work and Non-work Roles: Implications for the Career Planning Process."

22. C. K. Holahan and L. A. Gilbert, "Conflict Between Major Life Roles: Women and Men in Dual Career Couples," Human Relations (June 1979), pp. 451-67.

23. S. Deng, L. Hassan, and S. Jivan, "Female Entrepreneurs Doing Business in Asia: A Special Investigation, Journal of Small Business and Entrepreneurship 12, no. 20 (1995), pp. 60-80.

24. C. R. Stoner, I. R. Hartman, and R. Arora, "Work-Home Role Conflict in Female Owners of Small Businesses: An Exploratory Study, Journal of Small Business Management 28, no. 1 (1990), pp. 30-38; and R. J. Burke, "Work Experiences and Career Development and Professional Women," in M. J. Schabracq, J. A. Winnibst, and C. L. Cooper, eds., Handbook of Work and Health Psychology. New York: John Wiley \& Sons Ltd., 1996. 
25. While there have been a few studies on female entrepreneurs from the newly industrializing countries (e.g., Singapore), they have not focused specifically on the work-family conflicts of women entrepreneurs.

26. R. C. Maysami and V. P. Goby, "Female Business Owners in Singapore and Elsewhere: A Review of Studies," Journal of Small Business Management 37, no. 2, (1999), pp. 96-105.

27. Naik, Development Programme for Women in Management.

28. S. Small and E. Riley, "Towards a Multidimensional Assessment of Work Spillover into Family Life," Journal of Marriage and the Family 52 (1990), pp. 51-61.

29. Ibid.

30. For example, S. Aryee, "Antecedents and Outcomes of Work-Family Conflict Among Married Professional Women: Evidence from Singapore," Human Relations 45 (1992), pp. 813-837; and S. Aryee, "Dual-Earner Couples in Singapore: An Examination of Work and Non-work Sources of their Experienced Burnout," Human Relations 46, no. 12 (1993), pp. 1441-1459.

31. S. K. Teo, "Women Entrepreneurs of Singapore," in Low and Tan, eds., Singapore Business Development Series: Entrepreneurs, Entrepreneurship and Enterprising Culture. Singapore: AddisonWesley, 1996, pp. 254-89.

32. Ibid.

33. Keith and Shafer, "Role Strain and Depression in Two Job Families"; and Greenhaus and Kopelman, "Conflict Between Work and Non-work Roles: Implications for the Career Planning Process."

34. Holahan and Gilbert, "Conflict Between Major Life Roles: Women and Men in Dual Career Couples"; and Deng, Hassan, and Jivan, "Female Entrepreneurs Doing Business in Asia: A Special Investigation."

35. C. S. Granrose, S. Parasuraman, and J. Greenhaus, "A Proposed Model of Support Provided by TwoEarner Couples," Human Relations 45, no. 12 (1992), pp. 1367-1379.

36. Stoner, Hartman, and Arora, "Work-Home Role Conflict in Female Owners of Small Businesses: An Exploratory Study."

37. Ibid.

38. S. Dhaliwal, "Silent Contributors: Asian Female Entrepreneurs and Women in Business," Women's Studies international Forum 21, no. 5 (1998), pp. 463-74.

39. Ibid.

\section{Acknowledgment}

The research, on which this article is based, was funded by the Canadian International Development Agency (CIDA) through the Women in Development program of the Shastri Indo-Canadian Institute (SICI). Neither . CIDA nor SICl endorse the findings of this recearch.
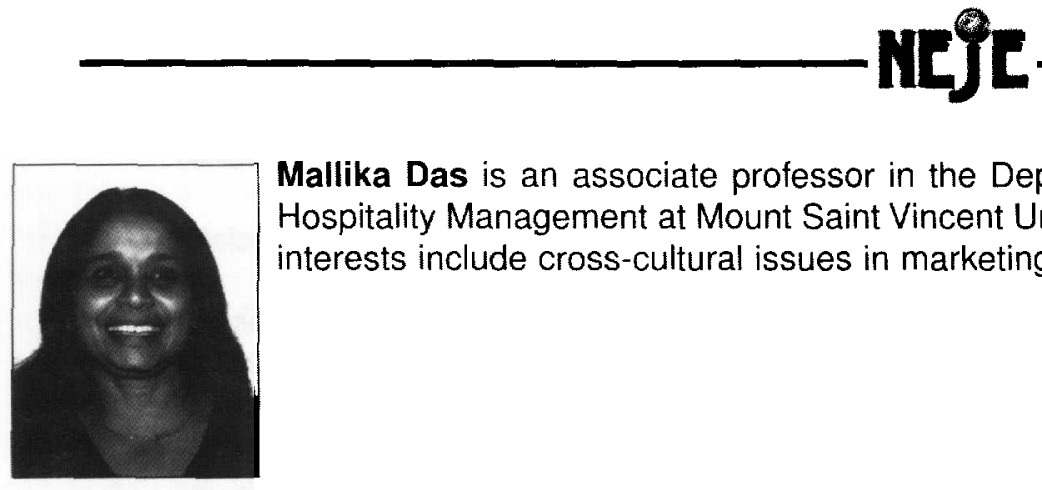

Mallika Das is an associate professor in the Department of Business Administration and Tourism and Hospitality Management at Mount Saint Vincent University in Halifax, Nova Scotia, Canada. Her research interests include cross-cultural issues in marketing and gender issues in business. 